\title{
Pengaruh Umur Terhadap Kadar Kholesterol, Trigliserida Dan Cooking Loss Daging Sapi Pesisir
}

\author{
Khasrad \\ Jurusan Produksi Ternak Fakultas Peternakan Universitas Andalas \\ Kampus Limau Manis Padang
}

\begin{abstract}
The research was carried out to study the effects of age to cholesterol content, trigliserida and cooking loss of meat pesisir cattle. Twelve cattle were allotted to a $4 \times 3$ randomized block design (RBD). The treatments are 4 levels of age, they are $I_{1}$ (1.5-2.0 years), $I_{2}$ (2.53.0 years), $I_{3}$ (3.5-4.0 years) and $I_{4}(>4.5$ years). The results showed that cholesterol content of meat pesisir cattle ranged from $37.24-38.29 \mathrm{mg} / 100$ gram, trigliserida 12.25 $-13.62 \mathrm{mg} / 100$ gram of meat and cooking loss ranged from $28.10-32.36 \%$. The age of cattle didn't influence significantly $(P>0.05)$ to cholesterol content and trigliserida content of meat, but cooking loss persentage decreased significantly $\quad(P<0.05)$ by increasing the age of cattle.
\end{abstract}

Key word: Cholesterol, trigliserida, cooking loss, Pesisir cattle

\section{Pendahuluan}

Permintaan daging untuk konsumsi dalam negeri terus meningkat dari tahun ke tahun, tetapi belum dapat diimbangi oleh peningkatan produktivitas ternak penghasil daging. Selain itu pertumbuhan penduduk, peningkatan pendapatan, kesadaran pangan dan gizi masyarakat, meningkatnya arus wisatawan luar ke Indonesia serta peluang ekspor ke beberapa negara di kawasan Asia Pasifik (Korea Selatan, Thailand, Taiwan, Hongkong dan Singapura) merupakan peluang baru dalam usaha peternakan, khususnya peternakan sapi pedaging yang berkualitas tinggi (Gurnadi, 1993).

Kualitas daging sapi lokal masih rendah dan belum memenuhi standar persyaratan yang dikehendaki. Apalagi sapi-sapi lokal kita umumnya berfungsi ganda yaitu sebagai penghasil daging dan sebagai tenaga kerja untuk mengolah lahan pertanian. Sapi-sapi yang dipekerjakan serat dagingnya menjadi kasar dan hemoglobinnya meningkat, hal ini menyebabkan daging sapi akan menjadi alot, $\mathrm{pH}$ daging tinggi dan warnanya menjadi lebih gelap.

Di lain pihak sapi-sapi lokal kita juga belum mempunyai standar kualitas, sehingga setiap potongan daging dinilai dengan harga yang sama. Begitu juga para distributor dan konsumen daging sangat minim sekali pengetahuannya tentang kualitas daging yang baik. Momen ini juga dimanfaatkan oleh importir daging untuk mempromosikan produknya dengan membuat image bahwa daging sapi impor kualitasnya lebih baik dari sapi lokal.

Untuk itu perlu penjelasan yang berkesinambungan dari pihak terkait (Dinas Peternakan, Perguruan Tinggi dan Lembaga Penelitian) tentang kualitas daging dan cara penanganan daging pasca panen. Beberapa penelitian untuk meningkatkan kualitas daging telah dilakukan tetapi penanganan pasca panen yang efektif 
dan ekonomis belum dapat didefinisikan secara pasti.

Penelitian tentang sifat-sifat daging belum banyak dilakukan di Indonesia. Di negara-negara maju, seperti Amerika Serikat, Itali dan Perancis penelitian tentang sifat-sifat daging telah banyak dilakukan, bahkan bagian-bagian daging pada karkas telah punya kelas mutu (grade) berdasarkan kualitasnya. Dengan adanya standar kualitas, peternak cenderung untuk memproduksi ternak dengan kualitas baik, sesuai permintaan konsumen.

Penelitian ini dilakukan dengan tujuan untuk mengetahui pengaruh umur terhadap kandungan kholesterol, trigliserida dan cooking loss daging sapi Pesisir. Dengan adanya penelitian ini tentu akan menjadi bahan tambahan bagi pemerintah dalam membuat standar kualitas daging sapi lokal. Apalagi saat ini daging sapi lokal kita belum mempunyai standar yang baku seperti yang ada di luar negeri. Dengan adanya standar kualitas daging nasional tentu kita bisa menetapkan harga sesuai dengan kualitasnya dan konsumen terbantu dalam mendapatkan daging sesuai dengan seleranya.

\section{Materi Dan Metode}

Dalam penelitian ini digunakan 12 ekor sapi Pesisir jantan yang dipotong di Rumah Potong Hewan Kota Padang. Pengambilan sampel daging dilakukan pada berbagai tingkat umur kronologis berdasarkan pergantian gigi seri, yaitu $I_{1}(1,5-2,0$ tahun), $I_{2}$ (2,5-3,0 tahun), $I_{3}$ (3,5-4,0 tahun) dan $\mathrm{I}_{4}$ ( $>4,5$ tahun). Sampel daging yang digunakan adalah otot Longissimus dorsi pada potongan rusuk 5-6 dari setengah karkas bagian kiri. Sampel daging kemudian di- analisa untuk mengetahui kandungan kholesterol, trigliserida dan cooking loss daging.

Analisis kandungan kholesterol dilakukan dengan dua tahap yaitu; Tahap I dengan ekstraksi dan tahap II dengan analisis.

a. Tahap Ekstraksi

Cara ekstraksi bahan untuk analisis kandungan kholesterol dilakukan sebagai berikut:

- Bahan diambil 1 gram kemudian ditambahkan $10 \mathrm{ml}$ aceton-etanol (1:1).

- Panaskan sampai mendidih di atas waterbath suhu $60{ }^{0} \mathrm{C}$ selama 15 menit.

- Pelarut yang tinggal disaring dengan kertas saring whatman 41.

- Larutkan kembali dengan $5 \mathrm{ml}$ aseton-etanol, uapkan pada suhu $60{ }^{\circ} \mathrm{C}$ selama 10 menit. Pelarut yang tersisa disaring dan diulang sampai dua kali.

- Selanjutnya hasil ekstraksi dipanaskan kembali sampai volume $1 \mathrm{ml}$ dan larutan ini dianalisa kadar kholesterolnya.

b. Tahap Analisis Kholesterol dengan Metode Boehringer.

Analisis kholesterol dengan metode Boehringer adalah sebagai berikut :

- Ambil $1 \mathrm{ml}$ reagen (kit) kholesterol boehringer dan dipipetkan kedalam tabung reaksi, kemudian ditambahkan hasil ekstraksi sebanyak 0.01 $\mathrm{ml}$.

- Larutan diguncang perlahanlahan selama 15 menit sampai kholesterol bereaksi dengan ekstraksi yang ditandai dengan perubahan warna.

- Setiap seri dibuat blangko untuk membandingkan perubahan warna. 
- Kemudian dibaca dengan menggunakan spectrometer merk clinicon pada panjang gelombang 546 dengan faktor 853.

Trigliserida dianalisa dengan cara berikut:

- Ambil $2 \mathrm{ml}$ reagen trigliserida masukkan kedalam bahan hasil ekstraksi sebanyak $0,02 \mathrm{ml}$ ditunggu sampai terjadinya reaksi reagen trigliserida dengan ekstraksi yang ditandai dengan perubahan warna.

- Untuk setiap seri pemeriksaan dibuat blanko untuk membandingkan perubahan warna.

- Kemudian hasil reaksi tersebut dibaca dengan menggunakan spektrofotometer pada panjang gelombang 546 dengan faktor 4010.

- Angka yang tertera pada spektrofotometer merupakan kandungan trigliserida yang teresterifikasi.

Cooking Loss diukur dengan cara berikut:

- Timbang sampel daging seberat 100 gr, lalu rebus selama lebih kurang 1 jam pada temperatur $80^{\circ} \mathrm{C}$.
- Bilas dengan kertas tissu lalu ditimbang kembali.

- Hitung selisih antara berat sebelum dimasak dengan sesudah dimasak.

- Kemudian hasil ini dipresentasekan terhadap berat sebelum dimasak.

Data hasil penelitian ini dianalisa secara statistik dengan analisa keragaman menggunakan Rancangan Acak Kelompok, dimana sebagai kelompok adalah hari pengambilan sampel. Sebagai perlakuan adalah 4 tingkatan umur sapi Pesisir yang terdiri dari 4 taraf yaitu $I_{1}$ (1,5-2,0 tahun), $I_{2}$ (2,5-3,0 tahun), $I_{3}$ (3,5-4,0 tahun) dan $\mathrm{I}_{4}(>4,5$ tahun).

\section{Hasil Dan Pembahasan}

Rataan kandungan kholesterol, trigliserida dan cooking loss daging sapi Pesisir pada masing-masing tingkat umur dapat dilihat pada Tabel 1 .

Dari hasil analisis keragaman diketahui bahwa tidak terdapat pengaruh umur $(\mathrm{P}>0,05)$ terhadap kandungan kholesterol dan trigliserida daging. Sedangkan cooking loss dipengaruhi oleh umur sapi, dimana semakin tinggi umur sapi persentase cooking loss semakin besar.

Tabel 1. Rataan Kandungan Kholesterol, Trigliserida dan Cooking Loss Daging Sapi Pada Berbagai Tingkat Umur

\begin{tabular}{cccc}
\hline Tingkat Umur & $\begin{array}{c}\text { Kholesterol } \\
(\mathrm{mg} / 100 \mathrm{~g})\end{array}$ & $\begin{array}{c}\text { Trigliserida } \\
(\mathrm{mg} / 100 \mathrm{~g})\end{array}$ & $\begin{array}{c}\text { Cooking Loss } \\
(\%)\end{array}$ \\
\hline $\mathrm{I}_{1}(1,5-2 \mathrm{th})$ & 37,65 & 13,62 & $32,36^{\mathrm{a}}$ \\
$\mathrm{I}_{2}(2,5-3 \mathrm{th})$ & 38,29 & 12,89 & $31,94^{\mathrm{a}}$ \\
$\mathrm{I}_{3}(3,5-4 \mathrm{th})$ & 37,24 & 12,25 & $28,75^{\mathrm{b}}$ \\
$\mathrm{I}_{4}(>4,5$ th) & 38,02 & 13,47 & $28,10^{\mathrm{b}}$
\end{tabular}

Keterangan : Superskrip yang berbeda pada kolom yang sama menunjukkan Perbedaan yang nyata $(\mathrm{P}<0,05)$. 
Kandungan kholesterol daging sapi pesisir berkisar antara 37,24 $38,29 \mathrm{mg} / 100$ gram. Dari hasil uji statistik diketahui bahwa umur sapi tidak berpengaruh nyata $(\mathrm{P}<0.05)$ terhadap kandungan kolesterol. Hal ini berarti penimbunan lemak pada daging sapi Pesisir atau yang disebut dengan lemak intramuskuler samgat rendah. Selain itu juga sapi Pesisir umumnya dipelihara secara tradisional yang hanya diberi hijauan saja, sehingga penimbunan lemak intramuskuler sedikit. Anggorodi (1994) menyatakan bahwa kekurangan zat makanan memperlambat puncak pertumbuhan urat daging dan memperlambat laju penimbunan lemak, sedangkan makanan yang sempurna mempercepat terjadinya laju puncak dari keduanya. Sedangkan menurut Eichhorn et al., (1986) dikutip oleh Komariah (1997) kandungan kholesterol daging sapi pada Muskullus Longissimus Dorsi adalah $58.3 \mathrm{mg} / 100$ gram.

Faktor yang mempengaruhi kandungan kholesterol ini adalah tata laksana pemeliharaan dan lingkungan yang akan mempengaruhi lemak intramuskuler (lemak tubuh). Tu et al., (1967) yang dikutip oleh Arnim (1992) menyatakan kandungan kholesterol pada daging sapi dan babi akan meningkat dengan naiknya persentase lemak intramuscular dalam daging, dimana kandungan lemak daging sangat bervariasi dan dipengaruhi oleh beberapa faktor antara lain : macam dan jenis makanan, aktifitas fisik dan faktor keturunan.

Komariah (1997) mendapatkan kandungan kholesterol sapi Bali nyata lebih rendah dari sapi $\mathrm{PO}(\mathrm{P}<0,05)$. Hal ini kemungkinan disebabkan karena sumber kholesterol tidak hanya dari lemak intramuskular tetapi juga adanya kandungan asetat yang berasal dari ransum. Sapi Bali lebih mampu mencerna hijauan dengan serat kasar tinggi dibandingkan sapi $\mathrm{PO}$, sehingga produk asetatnya tinggi dimana asam asetat tersebut akan diubah menjadi mevalonat dan akhirnya menjadi kholesterol.

Montgomery et al., (1983), menyatakan bahwa penggantian asam empedu dilakukan dengan sintesis dari kholesterol dalam hati. Dengan memberikan pengikat asam empedu (misalnya serat dari makanan) maka akan menurunkan reabsorbsi asam empedu dari usus dan dengan demikian meningkatkan pengeluaran asam empedu dalam feses. Untuk memperoleh imbangan terhadap pengeluaran yang lebih besar, maka lebih banyak kholesterol yang harus diubah menjadi asam empedu dalam hati, sehingga akan lebih banyak kholesterol yang diambil dari plasma darah. Hal ini sangat menguntungkan karena akan dapat menurunkan kholesterol dalam plasma darah. Menurut Siswanto et al., (1996) kadar lemak tubuh mempunyai korelasi positif dengan kandungan kholesterol tubuh. Apabila kadar lemak tubuh meningkat maka kandungan kholesterol tubuh juga akan bertambah.

Rataan kandungan trigliserida sapi Pesisir berkisar antara 12,25 $13,62 \mathrm{mg} / 100$ gram. Dari hasil uji statistik diketahui bahwa umur sapi tidak berpengaruh nyata $(\mathrm{P}>0,05)$ terhadap kandungan trigliserida.

Kandungan trigliserida juga sangat berkaitan dengan penimbunan lemak pada daging. Pada sapi Pesisir ini jumlah lemak intramuskuler ini sangat rendah, karena peternak jarang sekali memberikan konsentrat pada sapinya sehingga cadangan energinya rendah sekali. Menurut Soeparno (1998) variasi komposisi tubuh sebagian besar didominasi oleh variasi 
berat tubuh dan sebagian kecil dipengaruhi oleh umur. Variasi komposisi tubuh yang terbesar adalah jumlah lemak.

Anggorodi (1994) menjelaskan sifat lemak tubuh dipengaruhi secara nyata oleh makanannya. Apabila ransum mengandung kadar lemak yang tinggi maka mengakibatkan lemak dalam bahan makanan mempunyai pengaruh yang menen-tukan sifat lemak dalam tubuh, hal ini disebabkan asam-asam lemak dalam lemak bahan makanan disimpan dalam tubuh dengan tidak megalami perubahan.

Dari hasil uji statistik juga diketahui bahwa umur ternak berpengaruh nyata $(\mathrm{P}<0,05)$ terhadap persentase cooking loss daging. Semakin lama umur ternak maka persentase cooking loss semakin kecil. Hal ini kemungkinan disebabkan karena pada sapi yang lebih muda banyak mengandung air bebas sehingga kehilangan selama pemasakan akan semakin besar. Begitu juga sebaliknya pada hewan tua seratserat ototnya lebih panjang dan ikatan silangnya lebih banyak, sehingga gugus reaktif proteinnya dalam mengikat air lebih kuat. Dengan demikian kehilangan air selama pemasakan semakin kecil.

Hasil uji Duncan diketahui bahwa perlakuan A1 tidak berbeda nyata dengan $\mathrm{A} 2$, tetapi berbeda nyata dengan perlakuan A3 dan A4. Sedangkan perlakuan A3 tidak berbeda nyata dengan perlakuan A4. Rataan nilai cooking loss atau susut masak selama penelitian berkisar antara $28,10-32,36 \%$. Nilai tersebut lebih rendah dari nilai yang dikemukakan oleh Lawrie (1985) yaitu $40,5 \%$. Perbedaan nilai tersebut kemungkinan disebabkan oleh banyak hal, seperti materi yang digunakan dalam penelitian, waktu pengambilan data, besar potongan daging contoh, teknis perebusan dan lain sebagainya.

\section{Kesimpulan}

Dari penelitian yang telah dilakukan dapat disimpulkan bahwa umur sapi tidak berpengaruh nyata $(\mathrm{P}>0,05)$ terhadap kandungan kholesterol dan trigliserida daging sapi Pesisir. Sedangkan persentase cooking loss dipengaruhi oleh umur sapi. Semakin tua umur sapi persentase cooking loss semakin rendah

\section{Daftar Pustaka}

Anggorodi, R. 1994. Ilmu Makanan ternak Umum. Gramedia, Jakarta.

Arnim. 1992. Komposisi Asam Lemak dan Kandungan Kholesterol Lemak Pelvis serta Kandungan Energi Daging Sapi Peranakan Brahman dan Kerbau dengan Sumber Energi Ransum yang Berbeda. Disertasi Doktor. Program Pascasarjana IPB, Bogor.

Gurnadi, E. 1993. Peranan PMA dan PMDN dalam Memenuhi Permintaan Daging Sapi Kualitas Ekspor. Lokakarya Strategi Operasional Investasi dan Perdagangan Agro-Industri Sapi Potong, Jakarta.

Komariah. 1997. Kandungan Kholesterol Daging Sapi Bali, Peranakan Ongole (PO) dan Kerbau pada Umur Yang Berbeda. Media Peternakan, Vol 22, No. 1. Fakultas Peternakan Institut Pertanian Bogor.

Lawrie, R.A. 1985. Meat Science. Pergamon Oxford. New York, 
Toronto, Sidney, Paris, Hewan, Universitas Udayana, Frankfurt. Denpasar.

Montgomery, R., Robert, L. Dryer, Soeparno. 1998. Ilmu dan Teknologi Thomas, W. Athur A. Spector. Daging. Gajah Mada University 1983. Biokimia Suatu Pendekatan Berorientasi Kasus. Gajah Mada University Press, Yokyakarta.

Siswanto, I.A.P. Utami, I.N. Wandia, B. Matram. 1996. Pengaruh Lemak Sapi dan Dedak Padi dalam Ransum Terhadap Kadar Total Lemak dan Kholesterol dalam hati Ayam Potong Jantan. Program Studi Kedokteran Press. Yogyakarta.

Steel, R.G.D. dan J.H. Torrie. 1980. Prinsip dan Prosedur Statistika. Suatu Pendekatan Biometrik, Gramedia Pustaka Utama, Jakarta.

Tu, C., W.D. Powrie dan Pennema. 1967. Free and esterifield cholesterol content of animal muscle and meat products. J. Food. Sci. 32:30-34.

Alamat Korespondensi: Dr. Ir. Khasrad, MS

Jurusan Produksi Ternak

Fakultas Peternakan Universitas Andalas

Kampus Limau Manis Padang

Artikel diterima 13 September 2006, disetujui 10 Oktober 2006 